\title{
Diphenyl (4'-(Aryldiazenyl)biphenyl-4-ylamino) (pyridin-3-yl)methylphosphonates as Azo Disperse Dyes for Dyeing Polyester Fabrics
}

\author{
Mohamed F. Abdel-Megeed, ${ }^{1}$ Mohamed M. Azaam, ${ }^{1}$ and Gamal A. El-Hiti ${ }^{1,2}$ \\ ${ }^{1}$ Department of Chemistry, Faculty of Science, University of Tanta, Tanta 31527, Egypt \\ ${ }^{2}$ School of Chemistry, Cardiff University, Main Building, Park Place, Cardiff CF10 3AT, UK \\ Correspondence should be addressed to Gamal A. El-Hiti; el-hitiga@cardiff.ac.uk
}

Received 17 June 2012; Accepted 23 August 2012

Academic Editor: Ana Cristi Basile Dias

Copyright (C) 2013 Mohamed F. Abdel-Megeed et al. This is an open access article distributed under the Creative Commons Attribution License, which permits unrestricted use, distribution, and reproduction in any medium, provided the original work is properly cited.

\begin{abstract}
Diphenyl (4'-aminobiphenyl-4-ylamino)(pyridin-3-yl)methylphosphonate (1) was synthesized in $88 \%$ yield from reaction of pyridine-3-carboxaldehyde with benzidine and triphenylphosphite in the presence of titanium tetrachloride as a catalyst. Diazotization of $\mathbf{1}$ gave the corresponding diazonium salt $\mathbf{2}$ which was coupled with several hydroxyl or amino compounds to give

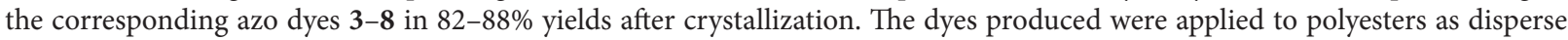
dyes and their fastness properties were elevated.
\end{abstract}

\section{Introduction}

The unique biological activities and characteristic chemical structures have made synthesis $\alpha$-aminophosphate derivatives attractive over the years [1]. Synthesis of $\alpha$-aminophosphates provides numerous compounds with various pharmacological activities [2-17].

The growth of the spinning and weaving industry prompted researchers to develop synthetic dyes to satisfy different industrial demands [18]. The most important class of synthetic dyes is azo dyes that form along with pigments the largest group of synthetic colorants that play prominent role in various applications.

As part of our continuing interest in organic synthesis [19-22], we have developed efficient syntheses of various substituted heterocycles [23-38]. Also, we have reported a simple and convenient approach for the synthesis of a series of azodisperse dyes [39]. We now report the successful synthesis of new azodisperse dyes containing $\alpha$-aminophosphonates and their application for dyeing polyester fabrics.

\section{Experimental}

Melting point determinations were performed by the open capillary method using an Electrothermal MEL-TEMP II apparatus and are reported uncorrected. IR spectra were recorded on a Perkin-Elmer 1430 Spectrophotometer using $\mathrm{KBr}$ disc technique. ${ }^{1} \mathrm{H}$ NMR spectra were recorded on a Bruker AC400 spectrometer operating at $400 \mathrm{MHz}$. The spectra were recorded in DMSO- $d_{6}$. Chemical shifts $\delta$ are reported in parts per million (ppm) relative to TMS and coupling constants $J$ are in $\mathrm{Hz}$ and have been rounded to the nearest whole number. Assignments of signals are based on integration values and expected chemical shift values and have not been rigorously confirmed. EI mass spectra were recorded at energy $70 \mathrm{eV}$ with a $7070 \mathrm{EQ}$ mass spectrometer. Microanalyses were performed by analytical service at both the Universities of Tanta and Cairo, Egypt. Analytical thin layer chromatography (TLC) was performed on EM silica gel $\mathrm{F}_{254}$ sheet $(0.2 \mathrm{~mm})$ with chloroform/acetone $(5: 2$ by volume) as a developing eluent. The spots were detected with 
UV Lamp Model UV GL-58. Reagents and solvents were used from commercial sources without purification.

2.1. Synthesis of Diphenyl (4'-Aminobiphenyl-4-ylamino) (pyridin-3-yl)methylphosphonate (1). A mixture of pyridine3-carboxaldehyde $(1.07 \mathrm{~g}, 10 \mathrm{mmol})$, benzidine $(1.84 \mathrm{~g}$, $10 \mathrm{mmol})$, triphenylphosphite $(3.72 \mathrm{~g}, 12 \mathrm{mmol})$, and titanium tetrachloride $(0.19 \mathrm{~g}, 1 \mathrm{mmol})$ in dichloromethane $(10 \mathrm{~mL})$ was stirred at room temperature for $26 \mathrm{~h}$. The solvent was removed under reduced pressure, and the residue obtained was treated with methanol $(20 \mathrm{~mL})$ and then filtered to remove the solid materials. A mixture of water $(10 \mathrm{~mL})$ and dichloromethane $(10 \mathrm{~mL})$ was added to the filtrate. The organic layer was separated and washed with water $(10 \mathrm{~mL})$, dried over anhydrous $\mathrm{Na}_{2} \mathrm{SO}_{4}$, and removed under reduced pressure to give the crude product which was recrystallized from ethanol to give pure 1 in $88 \%$ yield as colorless solid; m.p. $120-122^{\circ}$ C. IR $\left(\mathrm{KBr}, v_{\max }\right): 3329,1597,823 \mathrm{~cm}^{-1}$. ${ }^{1} \mathrm{H}$ NMR (400 MHz, DMSO- $d_{6}$ ): $\delta 10.17$ (br s, exch., $1 \mathrm{H}$, $\mathrm{NH}), 9.15-6.76(\mathrm{~m}, 22 \mathrm{H}$, aromatic), $5.16(\mathrm{~d}, J=16 \mathrm{~Hz}, 1 \mathrm{H}$, $\mathrm{CH}), 3.97$ (s, exch., $\left.2 \mathrm{H}, \mathrm{NH}_{2}\right)$. MS ( $\left.m / z, \%\right): 507\left(\mathrm{M}^{+}, 5\right)$, 449 (12), 390 (22), 314 (35), 265 (44), 396 (5), 225 (100), 214 (12), 168 (11). Analyses Calcd. for $\mathrm{C}_{30} \mathrm{H}_{26} \mathrm{~N}_{3} \mathrm{O}_{3} \mathrm{P}$ : C, 71.00; H, 5.16; N, 8.28; P, 6.10\%. Found: C, 71.12; H, 4.94; N, 8.01; P, 6.15\%.

2.2. General Procedure for the Synthesis of Compounds 3-8. A cold $\left(0^{\circ} \mathrm{C}\right)$ solution of sodium nitrate $(0.76 \mathrm{~g}, 11 \mathrm{mmol})$ in $\mathrm{H}_{2} \mathrm{O}(10 \mathrm{~mL})$ was added gradually to a cold $\left(0^{\circ} \mathrm{C}\right)$ suspension of $1(5.07 \mathrm{~g}, 10 \mathrm{mmol})$ in conc. $\mathrm{HCl}(5 \mathrm{~mL})$. The diazonium salt 2 thus obtained was added with continuous stirring to a cold $\left(0^{\circ} \mathrm{C}\right)$ solution of coupler $(10 \mathrm{mmol})$ in aqueous $\mathrm{NaOH}$ solution $(10 \%, 15 \mathrm{~mL})$. The mixture was stirred at $0^{\circ} \mathrm{C}$ for 30 min and the dye obtained was filtered, washed with $\mathrm{H}_{2} \mathrm{O}$, dried, and crystallized from ethanol to give products 3-8.

2.2.1. Diphenyl (4'-((4-Hydroxynaphthalen-1-yl)diazenyl)biphenyl-4-ylamino)(pyridin-3-yl)methylphosphonate (3). Yield $88 \%$; rubine; m.p. $179-181^{\circ} \mathrm{C}$. IR $\left(\mathrm{KBr}, v_{\max }\right)$ : 3494,1613 , $1581,1323,893 \mathrm{~cm}^{-1}$. ${ }^{1} \mathrm{H}$ NMR $\left(400 \mathrm{MHz}, \mathrm{DMSO}-d_{6}\right): \delta 9.10$ (s, exch., $1 \mathrm{H}, \mathrm{OH}$ ), 8.73 (br s, exch., $1 \mathrm{H}, \mathrm{NH}$ ), 8.50-7.21 (m, $28 \mathrm{H}, \mathrm{Ar}-\mathrm{H}), 6.95$ (d, $J=12 \mathrm{~Hz}, 1 \mathrm{H}, \mathrm{CH}) . \mathrm{MS}(\mathrm{m} / z, \%)$ : $662\left(\mathrm{M}^{+}, 3\right), 613$ (2), 531 (3), 439 (59), 410 (4), 396 (5), 362 (29), 273 (12), 98 (100). Analyses Calcd. for $\mathrm{C}_{40} \mathrm{H}_{31} \mathrm{~N}_{4} \mathrm{O}_{4} \mathrm{P}$ : C, 72.50; H, 4.72; N, 8.45; P, 4.67\%. Found: C, 72.62; H, 4.74; N, $8.41 ; \mathrm{P}, 4.65 \%$.

2.2.2. Diphenyl (4'-((2-Hydroxynaphthalen-1-yl)diazenyl)biphenyl-4-ylamino)(pyridin-3-yl)methylphosphonate (4). Yield 84\%; dark red; m.p. $190-193^{\circ} \mathrm{C}$; IR (KBr, $\left.v_{\max }\right): 3337,1613$, $1580,1325,890 \mathrm{~cm}^{-1}$. ${ }^{1} \mathrm{H}$ NMR $\left(400 \mathrm{MHz}, \mathrm{DMSO}-d_{6}\right): \delta 9.09$ (s, exch., $1 \mathrm{H}, \mathrm{OH}$ ), 8.81 (br s, exch., $1 \mathrm{H}, \mathrm{NH}$ ), 8.72-7.43 (m, $28 \mathrm{H}, \mathrm{Ar}-\mathrm{H}), 6.95$ (d, $J=12 \mathrm{~Hz}, 1 \mathrm{H}, \mathrm{CH})$. MS $(\mathrm{m} / z, \%)$ : $662\left(\mathrm{M}^{+}, 4\right), 613$ (4), 531 (6), 439 (66), 410 (6), 396 (4), 362 (32), 273 (15), 98 (100). Analyses Calcd. for $\mathrm{C}_{40} \mathrm{H}_{31} \mathrm{~N}_{4} \mathrm{O}_{4} \mathrm{P}$ : C, 72.50; H, 4.72; N, 8.45; P, 4.67\%. Found: C, 72.60; H, 4.77; N, 8.39; P, 4.69\%.
2.2.3. Diphenyl (4'-((2,4-Dihydroxyphenyl)diazenyl)biphenyl4-ylamino)(pyridin-3-yl)methylphosphonate (5). Yield 89\%; red violet; m.p. $171-173^{\circ} \mathrm{C}$. IR $\left(\mathrm{KBr}, v_{\max }\right): 3332,1610,1490$, $1320,896 \mathrm{~cm}^{-1} .{ }^{1} \mathrm{H}$ NMR $\left(400 \mathrm{MHz}, \mathrm{DMSO}-d_{6}\right): \delta 9.11(\mathrm{~s}$, exch., $1 \mathrm{H}, \mathrm{OH}$ ), 8.81 (br s, exch., $1 \mathrm{H}, \mathrm{NH}), 8.73$ (s, exch., 1 $\mathrm{H}, \mathrm{OH}), 8.50-7.08(\mathrm{~m}, 25 \mathrm{H}, \mathrm{Ar}-\mathrm{H}), 6.92$ (d, $J=13 \mathrm{~Hz}, 1 \mathrm{H}$, $\mathrm{CH}) ; \mathrm{MS}(\mathrm{m} / z, \%): 628\left(\mathrm{M}^{+}, 3\right), 564(4), 514(3), 436(25), 362$ (100), 282 (28), 273 (12). Analyses Calcd. for $\mathrm{C}_{36} \mathrm{H}_{29} \mathrm{~N}_{4} \mathrm{O}_{5} \mathrm{P}$ : C, 68.78; H, 4.65; N, 8.91; P, 4.93\%. Found: C, 68.62; H, 4.84; N, 8.86; P, $4.95 \%$.

2.2.4. Diphenyl (4'-((5-Amino-2-hydroxyphenyl)diazenyl)biphenyl-4-ylamino)(pyridin-3-yl)methylphosphonate (6). Yield $84 \%$; reddish burgundy; m.p. $149-152^{\circ} \mathrm{C}$; IR (KBr, $\left.v_{\max }\right)$ : 3399, 1613, 1582, 1327, $884 \mathrm{~cm}^{-1}$. ${ }^{1} \mathrm{H}$ NMR $(400 \mathrm{MHz}$, DMSO- $d_{6}$ ): $\delta 9.09$ (s, exch., $1 \mathrm{H}, \mathrm{OH}$ ), 8.81 (br s, exch., $1 \mathrm{H}$, $\mathrm{NH}), 8.72-6.93$ (m, $25 \mathrm{H}, \mathrm{Ar}-\mathrm{H}), 6.63$ (d, J = $13 \mathrm{~Hz}, 1 \mathrm{H}, \mathrm{CH})$, 6.37 (s, exch., $\left.2 \mathrm{H}, \mathrm{NH}_{2}\right)$. MS ( $\left.m / z ; \%\right): 627\left(\mathrm{M}^{+}, 3\right), 413(2)$, 362 (100), 282 (38), 273 (13), 152 (38). Analyses Calcd. for $\mathrm{C}_{36} \mathrm{H}_{30} \mathrm{~N}_{5} \mathrm{O}_{4} \mathrm{P}: \mathrm{C}, 68.89 ; \mathrm{H}, 4.82 ; \mathrm{N}, 11.16 ; \mathrm{P}, 4.94 \%$. Found: C, 68.62; H, 4.94; N, 11.01; P, 4.85\%.

2.2.5. 7-Amino-3-((4'-((diphenoxyphosphoryl)(pyridin-3-yl) methylamino)biphenyl-4-yl)diazenyl)-4-hydroxynaphthalene2-sulfonic Acid (7). Yield 83\%; burgundy; m.p. $161-163^{\circ} \mathrm{C}$. IR $\left(\mathrm{KBr}, v_{\max }\right): 3424,1675,1519,1299,1163,892 \mathrm{~cm}^{-1} \cdot{ }^{1} \mathrm{H}$ NMR (400 MHz, DMSO-d 6 ): 9.09 (s, exch., $1 \mathrm{H}, \mathrm{OH}$ ), 8.90 (s, exch., $1 \mathrm{H}, \mathrm{SO}_{3} \mathrm{H}$ ), 8.80 (br s, $1 \mathrm{H}, \mathrm{NH}$ ), 8.72-6.93 (m, 26 $\mathrm{H}, \mathrm{Ar}-\mathrm{H}), 6.75$ (d, $J=12 \mathrm{~Hz}, 1 \mathrm{H}, \mathrm{CH}), 6.83$ (s, exch., $2 \mathrm{H}$, $\left.\mathrm{NH}_{2}\right)$. MS ( $\left.m / z, \%\right): 757\left(\mathrm{M}^{+}, 6\right), 515$ (39), 439 (15), 362 (72), 282 (100), 273 (11). Analyses Calcd. for $\mathrm{C}_{40} \mathrm{H}_{32} \mathrm{~N}_{5} \mathrm{O}_{7}$ PS: C, 63.40; H, 4.26; N, 9.24; P, 4.09\%. Found: C, 63.62; H, 4.24; N, $9.21 ; \mathrm{P}, 4.15 \%$.

2.2.6. Diphenyl (4'-((2-Amino-5-methylphenyl)diazenyl)biphenyl-4-ylamino)(pyridin-3-yl)methylphosphonate (8). Yield $82 \%$; buff; m.p. $201-203^{\circ} \mathrm{C}$. IR (KBr, $\left.v_{\max }\right): 3408,1612,1582$, 1323, $890 \mathrm{~cm}^{-1}$. ${ }^{1} \mathrm{H}$ NMR $\left(400 \mathrm{MHz}, \mathrm{DMSO}-d_{6}\right) \delta=9.09$ (br s, exch., $1 \mathrm{H}, \mathrm{NH}$ ), 8.80-6.49 (m, $25 \mathrm{H}, \mathrm{Ar}-\mathrm{H}), 5.65$ (d, $J=12 \mathrm{~Hz}, 1 \mathrm{H}, \mathrm{CH}$ ), 5.26 (s, exch., $2 \mathrm{H}, \mathrm{NH}_{2}$ ), 2.30 (s, $3 \mathrm{H}$, $\left.\mathrm{CH}_{3}\right)$. MS (m/z, \%): $625\left(\mathrm{M}^{+}, 9\right), 442$ (15), 362 (100), 282 (97), 273 (40), 152 (95). Analyses Calcd. for $\mathrm{C}_{37} \mathrm{H}_{32} \mathrm{~N}_{5} \mathrm{O}_{3} \mathrm{P}$ : C, 71.03; H, 5.16; N, 11.19; P, 4.95\%. Found: C, 71.02; H, $5.04 ; \mathrm{N}, 11.01 ; \mathrm{P}, 4.85 \%$.

2.3. Dyeing Procedure. The fabric was dyed with dye (2\%; calculated by weight of the fabric) and Avolan IS (1\%; Bayer AG, Germany) as dispersing agent, kept at a liquor ratio of $20: 1$. The process was started at $60^{\circ} \mathrm{C}$; the temperature was then raised to $130^{\circ} \mathrm{C}$ over $30 \mathrm{~min}$ and maintained there for $1 \mathrm{~h}$. After cooling, the fabric was removed and then treated with a solution of $\mathrm{NaHSO}_{4}(2 \%), \mathrm{NaOH}(2 \%)$, and the dispersing agent Avolan IS (0.1\%) at $70^{\circ} \mathrm{C}$ for $30 \mathrm{~min}$. Finally, the fabric was rinsed and dried at $60^{\circ} \mathrm{C}$.

2.3.1. Colour Fastness Tests. The results are collected in Table 1. 
TABLE 1: Fastness properties of dyes 3-8.

\begin{tabular}{|c|c|c|c|c|c|c|c|c|}
\hline \multirow{2}{*}{ Compound } & \multirow{2}{*}{ Washing } & \multicolumn{2}{|c|}{ Perspiration } & \multicolumn{2}{|c|}{ Rubbing } & \multicolumn{2}{|c|}{ Sublimation } & \multirow{2}{*}{ Light (40 h) } \\
\hline & & Acid & Alkali & Dry & Wet & Alt & St & \\
\hline 3 & 5 & 4 & 5 & 4 & 5 & 5 & 4 & 7 \\
\hline 4 & 5 & 5 & 4 & 5 & 4 & 5 & 4 & 6 \\
\hline 5 & 4 & 5 & 5 & 5 & 4 & 5 & 5 & 5 \\
\hline 6 & 5 & 5 & 4 & 4 & 4 & 4 & 5 & 6 \\
\hline 7 & 5 & 4 & 5 & 4 & 5 & 4 & 4 & 5 \\
\hline 8 & 5 & 5 & 5 & 5 & 5 & 5 & 5 & 6 \\
\hline
\end{tabular}

Alt: alteration, St: staining, rate for light fastness: 5-8 (acceptable), 1-4 (not acceptable); rate for different fastness: 4-5 (acceptable), 1-3 (not acceptable).

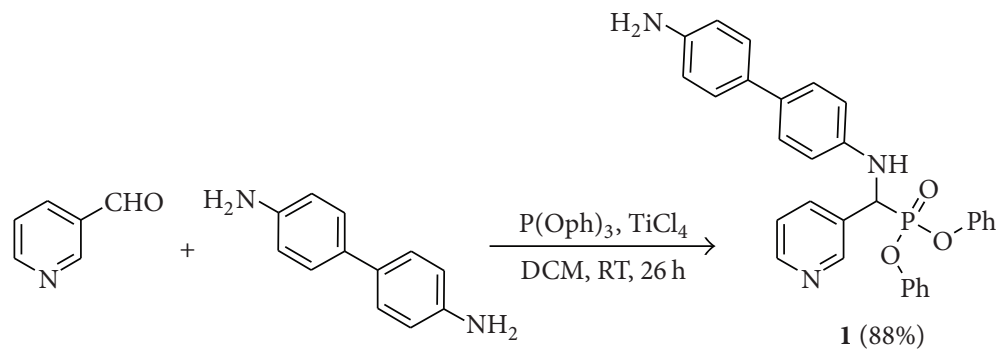

Scheme 1: Synthesis of diphenyl (4'-aminobiphenyl-4-ylamino)(pyridin-3-yl)methylphosphonate (1).

Fastness to Washing. A specimen of dyed polyester fabric was stitched between two pieces of undyed cotton fabric, all of equal length, and then washed at $50^{\circ} \mathrm{C}$ for $30 \mathrm{~min}$.

Fastness to Perspiration. The samples were prepared by stitching a piece of dyed polyester fabric between two pieces of undyed cotton fabric, all of equal length, and then immersed in the acid or alkaline solution for $30 \mathrm{~min}$. The acid solution $(\mathrm{pH}=3.5)$ contained sodium chloride $(10 \mathrm{~g} / \mathrm{L})$, lactic acid $(1 \mathrm{~g} / \mathrm{L})$, disodium orthophosphate $(1 \mathrm{~g} / \mathrm{L})$ and histidine monohydrochloride $(0.25 \mathrm{~g} / \mathrm{L})$. The alkaline solution $(\mathrm{pH}$ $=8)$ contained sodium chloride $(10 \mathrm{~g} / \mathrm{L}), \mathrm{NH}_{4} \mathrm{Cl}(4 \mathrm{~g} / \mathrm{L})$, disodium orthophosphate $(1 \mathrm{~g} / \mathrm{L})$, and histidine monohydrochloride $(0.25 \mathrm{~g} / \mathrm{L})$.

Fastness to Rubbing. The dyed polyester fabric was placed on the base of the Crockmeter, so that it rested flat on the abrasive cloth with its long dimension in the direction of rubbing. A square of white testing cloth was allowed to slide on the tested fabric back and forth twenty times by making ten complete turns of the crank according to the international standard procedure. For the wet rubbing test, the testing squares were thoroughly immersed in distilled water. The remaining procedure was the same as in the dry test.

Fastness to Sublimation. Sublimation fastness was measured with an iron tester (Yasuda no. 138). The samples were prepared by stitching a piece of dyed polyester fabric between two pieces of undyed polyester, all of equal length, and then treated at $180^{\circ} \mathrm{C}$ and $210^{\circ} \mathrm{C}$ each for $1 \mathrm{~min}$.

Fastness to Light. Light fastness was determined by exposing the dyed polyester on a Xenotest 150 (Original Hanau, chamber temperature $25-30^{\circ} \mathrm{C}$, black panel temperature $60^{\circ} \mathrm{C}$, relative humidity $50-60 \%$, and dark glass (UV filter system)) for $40 \mathrm{~h}$.

\section{Result and Discussion}

Diphenyl (4'-aminobiphenyl-4-ylamino)(pyridin-3-yl)methylphosphonate (1) was synthesized in $88 \%$ yield after crystallization from reaction of pyridine-3-carboxaldehyde, benzidine, and triphenylphosphite in the presence of a catalytic quantity of titanium tetrachloride $\left(\mathrm{TiCl}_{4}\right)$ as a Lewis acid in dichloromethane (DCM) for $26 \mathrm{~h}$ at room temperature (Scheme 1). The structure of 1 was confirmed by elemental analysis, IR, ${ }^{1} \mathrm{H}$ NMR, and mass spectral data (see Section 2 for details).

Diazotization of $\mathbf{1}$ was performed by using a mixture of sodium nitrite and hydrochloric acid to produce the corresponding diazonium salt $\mathbf{2}$. Coupling of $\mathbf{2}$ with several hydroxy or amino compounds, such as 1-naphthol, 2-naphthol, resorcinol, 2-aminophenol, 7amino-4-hydroxynaphthalene-2-sulfonic acid, and 4-toludine in aqueous sodium hydroxide solution afforded the corresponding diphenyl pyridin-3-yl(4'-(aryldiazenyl)biphenyl-4-ylamino)methylphosphonates 3-8 in high yields (82-89\%; Scheme 2).

The structures of diazo dyes 3-8 were confirmed by various spectroscopic techniques including IR, ${ }^{1} \mathrm{H}$ NMR and mass spectral data and their purities were confirmed by elemental analyses. The IR spectra of 3-8 are characterized by the presence of absorption bands within the $3494-3332 \mathrm{~cm}^{-1}$ region corresponding to the stretching vibrations of the $\mathrm{NH}$ and/or $\mathrm{OH}$ groups. The absorption bands at the $1582-1490 \mathrm{~cm}^{-1}$ region are due to the symmetric stretching 

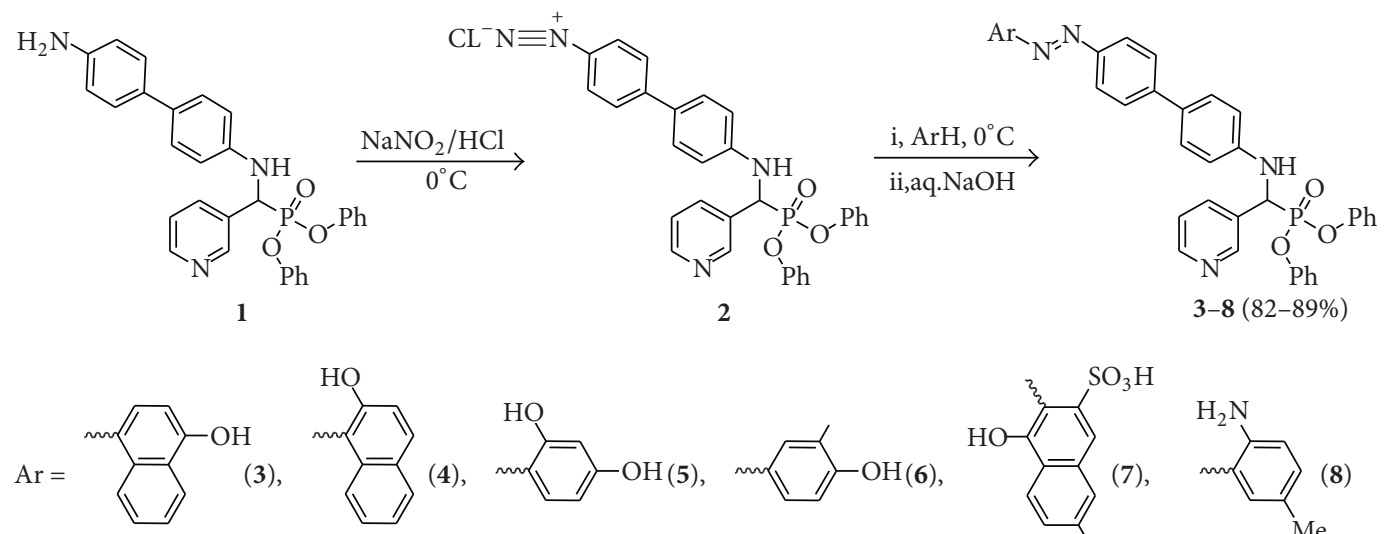

(3),<smiles>Cc1c(O)ccc2ccccc12</smiles>

$(4)$<smiles>Cc1ccc(O)cc1O</smiles>

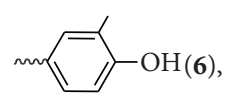<smiles>Cc1c(S(=O)(=O)O)cc2cc(N)ccc2c1O</smiles><smiles>Cc1ccc(N)c(C)c1</smiles>

Scheme 2: Synthesis of azo dyes 3-8.

vibrations of the azo group. The bands with the 1327-1299 and $896-884 \mathrm{~cm}^{-1}$ regions are due to the stretching vibrations of the $\mathrm{P}=\mathrm{O}$ and $\mathrm{P}-\mathrm{O}-\mathrm{C}$ groups, respectively. The ${ }^{1} \mathrm{H} \mathrm{NMR}$, spectra showed a characteristic $\mathrm{CH}$ doublet signal in the 6.95-5.65 ppm region. They also showed an exchangeable singlet signal that resonated in the $9.09-8.80 \mathrm{ppm}$ region due to the NH proton. The structures of diazo dyes 3-8 were confirmed further by mass spectral data. The electron impact mass spectra indicated the presence of molecular ion peaks in all cases. Moreover, the elemental analyses of 3-8 were consistent with the suggested structures and confirm the purities of the products (see Section 2 for details).

3.1. Dyeing of Polyester Fabrics and Dyeing Properties. Most influences that can affect fastness are light, washing, heat, perspiration, and atmospheric pollution. Conditions of such tests are chosen to correspond closely to the treatments employed in manufacture and of ordinary use conditions [40]. Results are given after usual matching of the tested samples against standard reference (the greyscale) [40]. The results obtained are shown in Table 1 . The results revealed that azo dyes 3-8 have good fastness properties.

\section{Conclusions}

A set of six useful disperse dyes 3-8 were synthesised by azo coupling. The dyes were investigated for their dyeing characteristics on polyester and showed good washing, perspiration, rubbing, sublimation and light fastness. The remarkable degree of brightness after washings is indicative of good penetration and the excellent affinity of these dyes for the fabric due to the accumulation of polar groups.

\section{Acknowledgment}

The authors are grateful to Mr. T. M. Zied, Misr Springing and Weaving Company, Mahala, Egypt, for his help in performing dyeing and fastness tests for the dyes.

\section{References}

[1] M. Ordóñez, H. Rojas-Cabrera, and C. Cativiela, "An overview of stereoselective synthesis of $\alpha$-aminophosphonic acids and derivatives," Tetrahedron, vol. 65, no. 1, pp. 17-49, 2009.

[2] M. Ordóňez, F. J. Sayago, and C. Cativiela, "Synthesis of quaternary $\alpha$-aminophosphonic acids," Tetrahedron, vol. 68, no. 32, pp. 6369-6412, 2012.

[3] R. Hirschmann, A. B. Smith, C. M. Taylor et al., "Peptide synthesis catalyzed by an antibody containing a binding site for variable amino acids," Science, vol. 265, no. 5169, pp. 234-237, 1994.

[4] C. B. Reddy, K. S. Kumar, M. A. Kumar et al., "PEG-SO3H catalyzed synthesis and cytotoxicity of a-aminophosphonates," European Journal of Medicinal Chemistry, vol. 47, pp. 553-559, 2012.

[5] C. Li, B. Song, K. Yan et al., "One pot synthesis of $\alpha$-aminophosphonates containing bromo and 3,4,5-trimethoxybenzyl groups under solvent-free conditions," Molecules, vol. 12, no. 2, pp. 163-172, 2007.

[6] G. S. Prasad, J. R. Krishna, M. Manjunath et al., "Synthesis, NMR, X-ray crystallography and bioactivity of some $\alpha$ aminophosphonates," Arkivoc, vol. 13, pp. 133-141, 2007.

[7] D. Y. Hu, Q. Q. Wan, S. Yang et al., "Synthesis and antiviral activities of amide derivatives containing the $\alpha$ aminophosphonate moiety," Journal of Agricultural and Food Chemistry, vol. 56, no. 3, pp. 998-1001, 2008.

[8] E. D. Naydenova, P. T. Todorov, M. N. Topashka-Ancheva et al., "Novel $N$-(phosphonomethyl) glycine derivatives: design, characterization and biological activity," European Journal of Medicinal Chemistry, vol. 43, no. 6, pp. 1199-1205, 2008.

[9] L. Tušek-Božić, M. Juribašić, P. Traldi, V. Scarcia, and A. Furlani, "Synthesis, characterization and antitumor activity of palladium(II) complexes of monoethyl 8-quinolylmethylphosphonate," Polyhedron, vol. 27, no. 4, pp. 1317-1328, 2008.

[10] B. Wang, Z. W. Miao, J. Wang, R. Y. Chen, and X. D. Zhang, "Synthesis and biological evaluation of novel naphthoquinone fused cyclic aminoalkylphosphonates and aminoalkylphosphonic monoester," Amino Acids, vol. 35, no. 2, pp. 463-468, 2008. 
[11] E. D. Naydenova, P. T. Todorov, P. I. Mateeva, R. N. Zamfirova, N. D. Pavlov, and S. B. Todorov, "Synthesis and biological activity of novel small peptides with aminophosphonates moiety as NOP receptor ligands," Amino Acids, vol. 39, no. 5, pp. 1537-1543, 2010.

[12] N. Oniţa, I. Şişu, M. Penescu, V. L. Purcarea, and L. Kurunczi, "Synthesis, characterization and biological activity of some $\alpha$ aminophosphonates," Farmacia, vol. 58, no. 5, pp. 531-545, 2010.

[13] X. Zhang, Y. Qu, X. Fan et al., "Solvent-free synthesis of pyrimidine nucleoside-aminophosphonate hybrids and their biological activity evaluation," Nucleosides, Nucleotides and Nucleic Acids, vol. 29, no. 8, pp. 616-627, 2010.

[14] J.-Z. Liu, B.-A. Song, H.-T. Fan et al., "Synthesis and in vitro study of pseudo-peptide thioureas containing $\alpha$ aminophosphonate moiety as potential antitumor agents," European Journal of Medicinal Chemistry, vol. 45, no. 11, pp. 5108-5112, 2010.

[15] J. Liu, S. Yang, X. Li et al., "Synthesis and antiviral bioactivity of chiral thioureas containing leucine and phosphonate moieties," Molecules, vol. 15, no. 8, pp. 5112-5123, 2010.

[16] C. Caldés, B. Vilanova, M. Adrover, F. Muñoz, and J. Donoso, "Understanding non-enzymatic aminophospholipid glycation and its inhibition. Polar head features affect the kinetics of Schiff base formation," Bioorganic and Medicinal Chemistry, vol. 19, no. 15, pp. 4536-4543, 2011.

[17] I. El Sayed, S. M. El Kosy, M. A. Hawata, A. A. El Gokha, A. Tolan, and M. M. Abd El-Sattar, "One-pot synthesis of novel $\alpha$ aminophosphonate derivatives containing a pyrazole moiety," American Journal of Science, vol. 7, pp. 357-361, 2011.

[18] A. Pandey, P. Singh, and L. Iyengar, "Bacterial decolorization and degradation of azo dyes," International Biodeterioration and Biodegradation, vol. 59, no. 2, pp. 73-84, 2007.

[19] K. Smith, G. A. El-Hiti, and A. Hamilton, "Unexpected formation of substituted anilides via reactions of trifluoroacetanilides with lithium reagents," Journal of the Chemical Society, Perkin Transactions 1, no. 24, pp. 4041-4042, 1998.

[20] K. Smith, G. A. El-Hiti, and A. P. Shukla, "Variation in site of lithiation with ring substituent of $N^{\prime}$-aryl- $N, N$-dimethylureas: application in synthesis," Journal of the Chemical Society, Perkin Transactions 1, no. 16, pp. 2305-2313, 1999.

[21] K. Smith, G. A. El-Hiti, and A. S. Hegazy, "Unexpected variations in sites of lithiation of $N$-(2-methoxybenzyl)- pivalamide," Synlett, no. 14, pp. 2242-2244, 2009.

[22] K. Smith, G. A. El-Hiti, A. S. Hegazy, A. Fekri, and B. M. Kariuki, "Variation in sites of lithiation of substituted $\mathrm{N}$ benzylpivalamides and $N^{\prime}$-benzyl- $N, N$-dimethylureas: application in synthesis," Arkivoc, vol. 14, pp. 266-300, 2009.

[23] K. Smith, G. A. El-Hiti, M. A. Abdo, and M. F. AbdelMegeed, "Regiospecific electrophilic substitution of aminoquinazolinones: directed lithiation of 3-(pivaloylamino)- and 3(acetylamino)-2-methylquinazolin-4(3H)- ones," Journal of the Chemical Society, Perkin Transactions 1, no. 8, pp. 1029-1033, 1995.

[24] K. Smith, G. A. El-Hiti, M. F. Abdel-Megeed, and M. A. Abdo, "Lithiation of 3-(acylammo)-2-unsubstituted-, 3-(acylamino)2-ethyl-, and 3-(acylamino)-2-propyl-4(3H)-quinazolinones: convenient syntheses of more complex quinazolinones," Journal of Organic Chemistry, vol. 61, no. 2, pp. 647-655, 1996.
[25] K. Smith, G. A. El-Hiti, M. F. Abdel-Megeed, and M. A. Abdo, "Lithiation of 2-alkyl-3-amino- and 2-alkyl-3-(methylamino)4(3H)-quinazolinones," Journal of Organic Chemistry, vol. 61, no. 2, pp. 656-661, 1996.

[26] K. Smith, G. A. El-Hiti, and S. A. Mahgoub, "Lithiation and sidechain substitution of 3-alkyl-1H-quinoxalin-2-ones," Synthesis, no. 15, pp. 2345-2348, 2003.

[27] K. Smith, G. A. El-Hiti, and A. C. Hawes, "Carbonylation of doubly lithiated $N^{\prime}$-aryl- $N, N$-dimethylureas: a novel approach to isatins via intramolecular trapping of acyllithiums," Synthesis, no. 13, pp. 2047-2052, 2003.

[28] G. A. El-Hiti, "A convenient procedure for the synthesis of novel modified 3-substituted $1 H$-quinoxaline-2-thiones via sidechain lithiation of 3-alkyl-1H-quinoxaline-2-thiones," Synthesis, no. 18, pp. 2799-2804, 2003.

[29] G. A. El-Hiti, "A convenient procedure for the formation of 2-substituted thiazolopyridines," Monatshefte fur Chemie, vol. 134, no. 6, pp. 837-841, 2003.

[30] G. A. El-Hiti, "A simple procedure for the side-chain lithiation of 2-alkyl-3H-quinazoline-4-thiones: application in synthesis," Synthesis, no. 3, pp. 363-368, 2004.

[31] G. A. El-Hiti, "Application of organolithium in organic synthesis: a simple and convenient procedure for the synthesis of more complex 6-substituted 3H-quinazolin-4-ones," Monatshefte fur Chemie, vol. 135, no. 3, pp. 323-331, 2004.

[32] K. Smith, G. A. El-Hiti, and M. F. Abdel-Megeed, "Regioselective lithiation of chiral 3-acylamino-2-alkylquinazolin-4(3H)ones: application in synthesis," Synthesis, no. 13, pp. 2121-2130, 2004.

[33] K. Smith, G. A. El-Hiti, and A. S. Hegazy, "A simple and convenient procedure for lithiation and side-chain substitution of 2-alkyl-4-(methylthio)quinazolines and 2-alkyl-4methoxyquinazolines," Synthesis, no. 17, pp. 2951-2961, 2005.

[34] K. Smith, G. A. El-Hiti, and A. S. Hegazy, "Lateral lithiation of $N^{\prime}$-(2-methylbenzyl)-N,N-dimethylurea and $N$-(2methylbenzyl)-pivalamide: synthesis of tetrahydroisoquinolines," Synthesis, no. 8, pp. 1371-1380, 2010.

[35] K. Smith, G. A. El-Hiti, A. S. Hegazy, and A. Fekri, "A simple and convenient high yielding synthesis of substituted isoindolines," Heterocycles, vol. 80, no. 2, pp. 941-956, 2010.

[36] K. Smith, G. A. El-Hiti, and A. S. Hegazy, "One-pot synthesis of substituted isoindolin-1-ones via lithiation and substitution of $N^{\prime}$-benzyl- $N, N$-dimethylureas," Chemical Communications, vol. 46, no. 16, pp. 2790-2792, 2010.

[37] K. Smith, G. A. El-Hiti, A. S. Hegazy, and B. Kariuki, "Simple and convenient one-pot synthesis of substituted isoindolin-1ones via lithiation, substitution and cyclization of $N^{\prime}$-benzyl$\mathrm{N}, \mathrm{N}$-dimethylureas," Beilstein Journal of Organic Chemistry, vol. 7, pp. 1219-1227, 2011.

[38] K. A. Browne, D. D. Deheyn, G. A. El-Hiti, K. Smith, and I. Weeks, "Simultaneous quantification of multiple nucleic acid targets using chemiluminescent probes," Journal of the American Chemical Society, vol. 133, no. 37, pp. 14637-14648, 2011.

[39] M. F. Abdel-Megeed, M. M. Azaam, and G. A. El-Hiti, "3-Arylazo-2-thioxo-2,3-dihydro- $1 H$-quinazolin-4-ones as azodisperse dyes for dyeing polyester fabrics," Monatshefte fur Chemie, vol. 138, no. 2, pp. 153-156, 2007.

[40] Anon, Standard Methods for the Determination of the Color Fastness of Textiles and Leather, Society of Dyes and Colorists, Bradford, UK, 5th edition, 1990. 

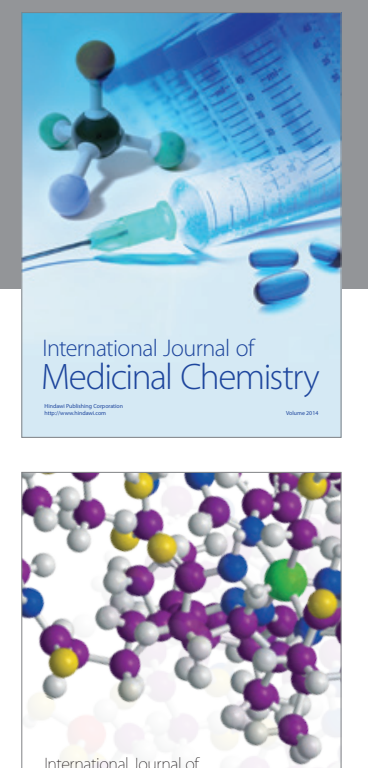

\section{Carbohydrate} Chemistry

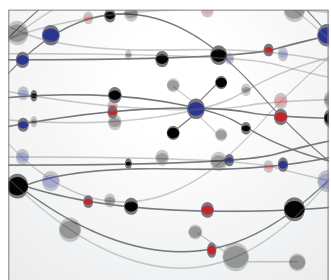

The Scientific World Journal
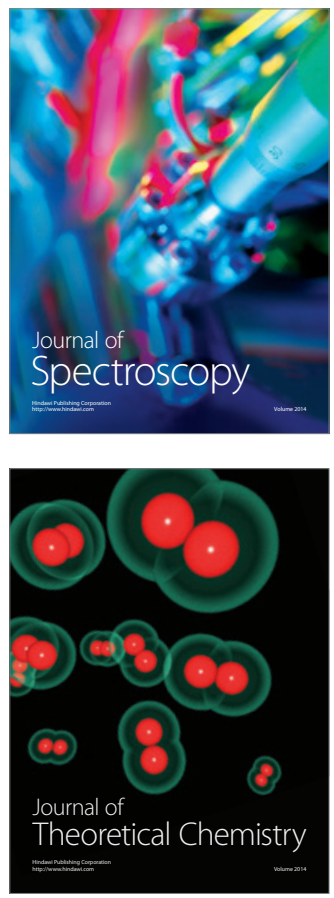
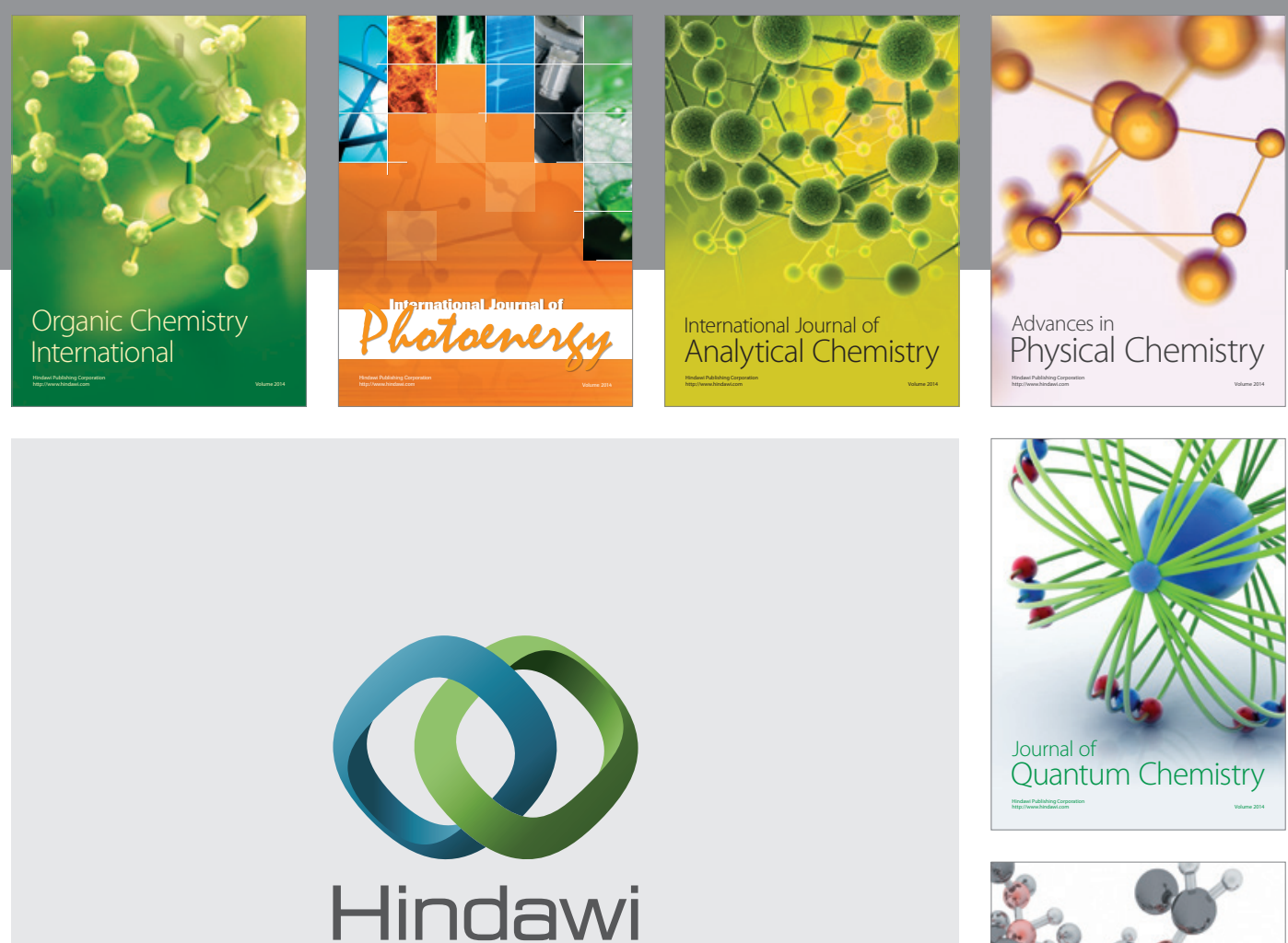

Submit your manuscripts at

http://www.hindawi.com

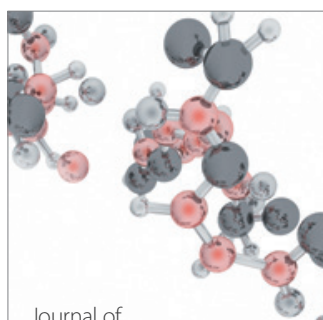

Analytical Methods

in Chemistry

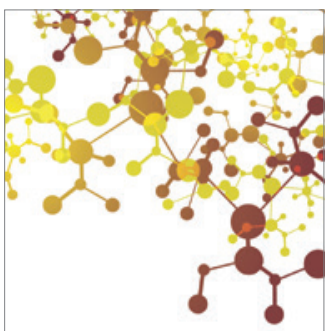

Journal of

Applied Chemistry

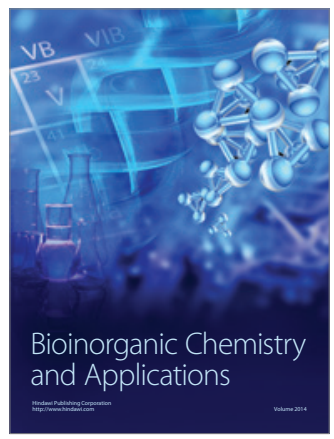

Inorganic Chemistry
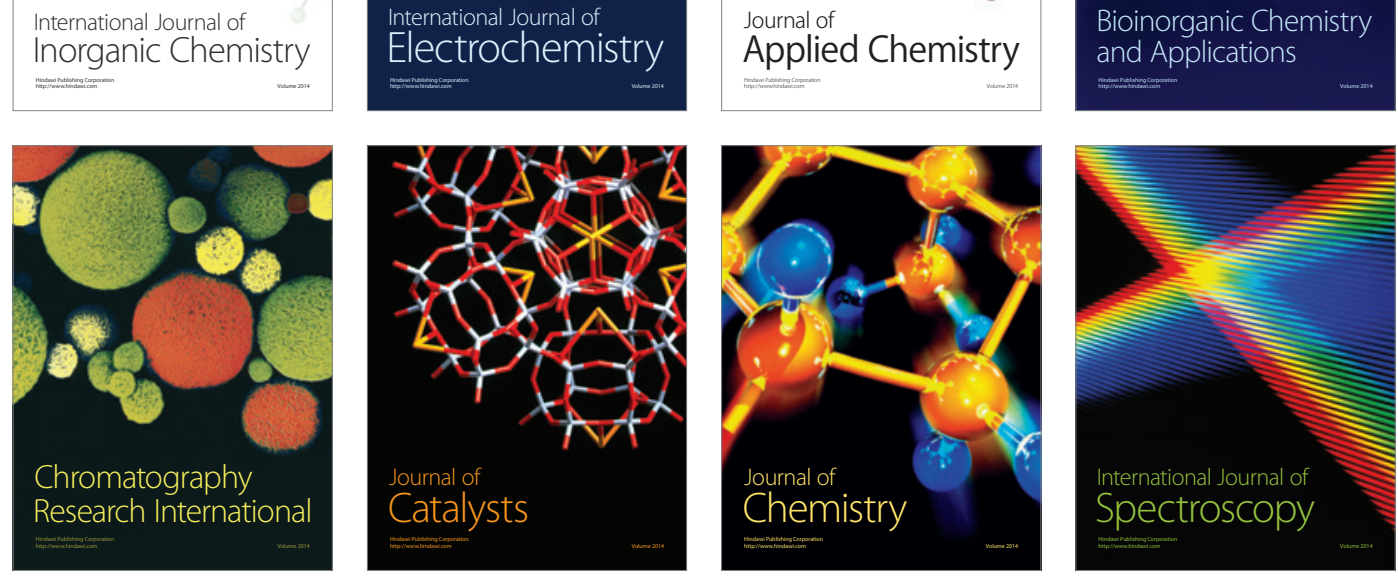